Research article

\title{
Physiological and biochemical changes attenuate the effects of drought on the Cerrado species Vatairea macrocarpa (Benth.) Ducke
}

\author{
Evandro Alves Vieira a, b, *, Maria das Graças Silva ${ }^{\text {b }}$, Camila Fernandes Moro ${ }^{\mathrm{c}}$, \\ Valdemir Antônio Laura ${ }^{\mathrm{d}, \mathrm{e}}$ \\ a Programa de Pós-Graduação em Biodiversidade Vegetal e Meio Ambiente, Instituto de Botânica, São Paulo, SP, Brazil \\ b Laboratório de Biologia, Universidade Estadual de Mato Grosso do Sul, Coxim, MS, Brazil \\ ${ }^{c}$ Programa de Pós-Graduação em Biologia Celular e Estrutural, Universidade Estadual de Campinas, Campinas, SP, Brazil \\ d Empresa Brasileira de Pesquisa Agropecuária-EMBRAPA, Campo Grande, MS, Brazil \\ e Programa de Pós-Graduação em Biologia Vegetal, Universidade Federal de Mato Grosso do Sul, Campo Grande, MS, Brazil
}

\section{A R T I C L E I N F O}

\section{Article history:}

Received 28 March 2017

Received in revised form

25 April 2017

Accepted 25 April 2017

Available online 26 April 2017

\section{Keywords}

Cerrado

Water deficit

Photosynthesis

Sucrose

Amino acids

Stomatal density

Relative growth rate

\begin{abstract}
A B S T R A C T
Drought is considered the main abiotic stress because it influences the distribution of plant species and limits the productivity of ecosystems. The aim of this study was to evaluate the effects of drought on physiological and biochemical parameters during the initial development of Vatairea macrocarpa, a native cerrado species. Plants were subjected to daily watering (control); suppression of watering during 90 days with field capacity (fc) $50 \%$ and $25 \%$ and then followed by rewatering. Relative leaf water content (RWC), gas exchange, photosynthetic pigments content, carbohydrate and amino acids content, antioxidant activities and growth were recorded. The RWC decreased according to the soil water restriction, causing reduction in stomatal conductance and decrease of $76.4 \%$ in net photosynthesis in plants submitted to $25 \% \mathrm{fc}$. Water restriction decreased the chlorophyll content, however increased carotenoid content and also improved the antioxidant activities of superoxide dismutase (SOD), ascorbate peroxidase (APX) and catalase (CAT). In addition, high levels of sugars (sucrose, raffinose) and amino acids (proline, tryptophan, valine, glutamine and GABA) were detected in drought stressed plants, contributing to osmoregulation and as sources of carbon and nitrogen after rehydration. Decreases in carbon assimilation promoted a reduction of the leaf area, however an increase in the root surface area was observed. After rewatering, the analized parameters became similar to the control plants indicating that the severe water stress did not impair the survival of young plants. Instead, adjustments were made to protect them against drought such as the maintenance of the assimilatory metabolism at minimal levels.
\end{abstract}

๑) 2017 Elsevier Masson SAS. All rights reserved.

\section{Introduction}

The Brazilian Cerrado represents a large tropical savannah area in the South America and contains a wealth of endemic species (approximately 44\%). Due to the high anthropic pressure which has been undergoing in the last decades (Myers et al., 2000) this biome is included among the critical areas for the biological diversity conservation (hotspots) in the world. About $20 \%$ of the original vegetation coverage remains intact and only $2.2 \%$ are located in areas of permanent preservation (Machado et al., 2004). In the

\footnotetext{
* Corresponding author. Programa de Pós-Graduação em Biodiversidade Vegetal e Meio Ambiente, Instituto de Botânica, São Paulo, SP, Brazil.

E-mail address: evieirae@gmail.com (E.A. Vieira).
}

Cerrado, woody species with up to $14 \mathrm{~m}$ length form the large covered areas while herbaceous plants with less than $2 \mathrm{~m}$ length constitute the rupestrian fields (Carvalho et al., 2012; Ball et al., 2015).

The seasonal contrast between the dry and rainy season and the high temperatures and irradiance are environmental features of the Cerrado. The periods of environmental stress lead to the redistribution of rainfall in many regions causing water deficit. These climate changes affect plant development and productivity (Oliveira and Marquis, 2002) especially in young plants (IPCC, 2007).

Knowledge of the physiological state of young plants under stress conditions is important to understand how the plant deals with biomass allocation according to environmental resources (soil water content). This usually involves compensatory mechanisms in 
root/shoot allocation providing more biomass to the organs that require more strongly the limiting resources (Robertson et al., 2009). Studies showing the effects of drought to different degrees have been reported. Grassi and Magnani (2005) observed a decrease in stomatal conductance followed by a reduction in photosynthetic rates in plants under moderate water deficit. Assaha et al. (2016) observed a super excitation of photosynthetic pigments with accumulation of reactive oxygen species (ROS) in plants under severe water deficit.

ROS are able to oxidize proteins and induce peroxidation of membrane phospholipids causing cellular damage (Assaha et al., 2016). Plants developed non-enzymatic and enzymatic mechanisms in order to minimize these effects. The non-enzymatic mechanisms are formed by low molecular weight antioxidants such as glutathione, ascorbic acid and carotenoids. The enzymatic mechanisms are composed of superoxide dismutase (SOD), glutathione peroxidase (GPX), catalase (CAT), ascorbate peroxidase (APX), among others (Apel and Hirt, 2004). Plant species submitted to abiotic stress presented an improvement in the antioxidant activity with the concomitant increase in free amino acids (Shukla et al., 2012; Toscano et al., 2016). Proline and glycine are important not only for osmotic control during drought, but also to protect cell membranes, detoxify ROS and stabilize enzymes and proteins (Ashraf and Foolad, 2007).

Cerrado conservation has been a major challenge due to lack of scientific information regarding the plant responses to environmental stresses that occur in the different physiognomies of this biome. Studies addressing native species have been carried out in greenhouse and in loco (Veiga and Habermann, 2013; Dalmolin et al., 2015; Garcia et al., 2015). However, little is known about the effects of drought on woody species from Cerrado. The recovery of degraded areas subject to drought extended periods is usually accomplished using seedlings of woody species. Therefore, the choice of the plant species to be used for this purpose should consider its ability to sufficiently tolerate drought in the early stages of development.

Vatairea macrocarpa (Benth.). Ducke is a woody species endemic to the Cerrado, which presents low frequency with irregular and discontinuous dispersion. It occurs preferentially in more open areas, developing on smooth slope in well-drained soil with medium fertility (Lorenzi, 2002). Identifying the functional diversity and life strategies of this species is essential to understand its functioning and ability to deal with the stress period. To our knowledge, no previous studies have demonstrated the ability of $V$. macrocarpa to deal with severe water deficit. Thus, the purpose of this study was to analyze the physiological and biochemical responses during the initial growth of $V$. macrocarpa plants submitted to drought.

Here, we demonstrate that young plants of $V$. macrocarpa presented resistance to drought due to physiological and biochemical changes, which were recovered after rehydration. These changes focused on the maintenance of assimilatory metabolism at minimum levels, osmotic adjustment and also on protective functions in plants. This work intend to contribute to the understanding of the behavior of an endemic species from Cerrado, which may be a candidate to be used in the recovery of degraded areas of this biome, since $V$. macrocarpa presented resistance to drought during the early stages of development.

\section{Material and methods}

\subsection{Study area}

The experiment was carried out from January to July in a greenhouse located at the State University of Mato Grosso do
Sul-UEMS, Brazil. The fruits and seeds of Vatairea macrocarpa were collected in a Cerrado sensu stricto area near the city of Coxim-MS $\left(18^{\circ} 30^{\prime} 08.3^{\prime \prime} \mathrm{S} ; 54^{\circ} 43^{\prime} 16.6^{\prime \prime} \mathrm{W}\right)$. Fruits of seven plants were collected at different points, being chosen those scattered on the ground and also in the treetops. The used substrate was collected from 0 to $20 \mathrm{~cm}$ of depth at 10 different points within collection area and then physical and chemical analysis were performed.

\subsection{Experimental conditions}

Seeds were germinated in a greenhouse with temperature $\left({ }^{\circ} \mathrm{C}\right)$, relative humidity $(\mathrm{RH} \%)$ and photosynthetically active radiation (PAR, $\mu$ mol photons $\mathrm{m}^{-2} \mathrm{~s}^{-1}$ ) monitored by a thermohygrometer (J. Prolab/SH122) and a quantum sensor (Li-190SA, Li-Cor-Nebraska, USA). When $V$. macrocarpa young plants reached $20 \mathrm{~cm}$ in length, the water restriction treatments were initiated: I - control group with daily irrigation, II - water deficit during 90 days with field capacity (fc) 50\%, III - water deficit during 90 days with $25 \%$ fc. After this period, the plants were rehydrated gradually until reaching fc $100 \%$. The fc value was evaluated using gravimetric method according to Lunt et al. (2005). Physiological and biochemical analysis were performed using middle portion of the third pair of fully expanded leaves (from apex to base).

\subsection{Leaf relative water content}

Relative water content (RWC) was calculated according the following equation: RWC (\%) $=(($ FW-DW/TW-DW $) \times 100)$. Leaf samples were collected, immediately weighed $(\mathrm{g})$ to obtain the fresh weight (FW) and then submerged in distilled water for $24 \mathrm{~h}$ to obtain the turgid weight (TW). Subsequently, the samples were placed in an oven at $60^{\circ} \mathrm{C}$ for $72 \mathrm{~h}$ to obtain the dry weight (DW).

\subsection{Gas exchange analysis}

Carbon assimilation rates $\left(A, \mu\right.$ mol $\left.\mathrm{CO}_{2} \mathrm{~m}^{-2} \mathrm{~s}^{-1}\right)$, stomatal conductance $\left(g s, \mathrm{~mol} \mathrm{~m}^{-2} \mathrm{~s}^{-1}\right)$ and transpiration $\left(E, \mu \mathrm{mol} \mathrm{H}_{2} \mathrm{O} \mathrm{m} \mathrm{m}^{-2}\right.$ $\mathrm{s}^{-1}$ ) were measured between 8:00 and 11:00 a.m. using a infrared gas analyzer LI-COR 6400 (LI-COR Inc., Lincoln, NE, USA). The measurements were done under controlled conditions of $\mathrm{CO}_{2}$ concentration (380 ppm), photosynthetic photon flux density (PPFD) of $700 \mu \mathrm{mol}$ photons $\mathrm{m}^{-2} \mathrm{~s}^{-1}$ at $25^{\circ} \mathrm{C}$. Water use efficiency (WUE) was calculated by the ration between carbon assimilation and amount of water transpired $(A / E)$.

\subsection{Chlorophyll and carotenoid content}

Chlorophylls and carotenoids content were quantified as described by Hendry and Price (1993), with minor modifications. Briefly, lyophilized leaves (100 mg) were ground and incubated with $3 \mathrm{~mL}$ of $80 \%(\mathrm{v} / \mathrm{v}$ ) acetone in the dark. After, $10 \mathrm{~mL}$ of the same solvent was added to the solution and then centrifuged at $3000 \mathrm{~g}$. The supernatant was analyzed by spectrophotometry (SP-22, Biospectro) at 480, 645 and $663 \mathrm{~nm}$ to obtain the concentration of chlorophyll $a, b$, and total carotenoid using the following equations:

Chlorophyll $a\left(\left(\mu \mathrm{mol} \mathrm{g}^{-1}\right)\right.$ : (12,7 x Abs 663)-(2,69 x Abs 645)) x V) / Ms) x 1,12

Chlorophyll $b$ ( $\left.\mu \mathrm{mol} \mathrm{g}^{-1}\right)$ : (22,9 x Abs 645)-(4,68 x Abs 663)) x V) / Ms) x 1,1

Total chlorophyll ( $\mu \mathrm{mol} \mathrm{g}^{-1}$ ): Chlorophyll $a+$ Chlorophyll $b$ 
Total carotenoid $\left(\mu \mathrm{mol} \mathrm{de}^{-1}\right)$ : ((Abs $480+(0,114 \times$ Abs 663$)-$ $(0,638 \times$ Abs 645$)) \times \mathrm{V}) /(112,5 \times \mathrm{Ms})$

$\mathrm{V}=$ volume of the extract solution and Ms = dry weight (mg).

\subsection{Carbohydrates content}

Leaf samples (200 mg) were lyophilized, ground and incubated with $80 \%$ ethanol in water bath at $80{ }^{\circ} \mathrm{C}$ for $15 \mathrm{~min}$. Total soluble carbohydrates were determined colorimetrically by the phenolsulfuric acid method (Dußois et al., 1956) using glucose (SigmaAldrich) as standard. Aliquots ( $1 \mathrm{~mL}$ ) were deionized using Dowex (Sigma-Aldrich) ion exchange columns, containing cation $50 \times 8$ (100-200 mesh) and anion $1 \times 8$ (52-100 mesh) exchange resins. The eluate was adjusted to $\mathrm{pH} 7.0$ adding $0.4 \mathrm{M} \mathrm{NH}_{4} \mathrm{OH}$. After the purification, samples were lyophilized and concentred to $400 \mu \mathrm{g} \mathrm{mL}^{-1}$ for total carbohydrate using deionized water. Soluble carbohydrates were identified by high-resolution ion-exchange chromatography (ICS 3000 Dionex, Thermo Scientific, USA) coupled to an amperometric pulse detector (HPAEC/PAD), using CarboPac $\mathrm{PA}^{-1}$ column $(2 \times 250 \mathrm{~mm})$. Oligosaccharides were excluded isocratically with $250 \mathrm{mM} \mathrm{NaOH}$ in a flow rate of $0.25 \mathrm{~mL} \mathrm{~min}^{-1}$. The peaks detected were compared with commercial standards to glucose, fructose, sucrose, raffinose and stachyose (Sigma-Aldrich). Starch was extracted using $10 \mathrm{mg}$ of residual soluble carbohydrates obtained from leaves and quantified according to the enzymatic method described by Caccere et al. (2013).

\subsection{Amino acid analysis}

Ground leaves (300 mg) were incubated with $10 \mathrm{~mL}$ of $6 \mathrm{~N} \mathrm{HCl}$ on ultrasound for $5 \mathrm{~min}$ and then placed in a digester block at $110{ }^{\circ} \mathrm{C}$ for $24 \mathrm{~h}$. An aliquot of $1 \mathrm{~mL} \mathrm{pH} 2.5$ was filtered in a Millex membrane $(0.22 \mu \mathrm{m}$ cut-off). Amino acid separation and analysis were performed using a high-performance liquid chromatography system (HPAEC/PAD). A total of $20 \mu \mathrm{L}$ of polar phase of the sample was injected in a chamber with elution in Shim-pack Amino-Na Shimpack/Ammonium Trap Column Shim-pack ISC-30 Na in a flow rate of $0.6 \mathrm{~mL} \mathrm{~min}{ }^{-1}$. Amino acid-OPA derivatives were detected using a set fluorescence monitor wave with $\lambda$ length excitation of $350 \mathrm{~nm}$ and $\lambda$ emission of $450 \mathrm{~nm}$. The concentrations of the amino acids were determined by comparison with commercial standard of Alanine (Ala), Arginine (Arg), Asparagine (Asn), Aspartate (Asp), Cysteine (Cys), Gamma aminobutyric acid (GABA), Glutamate (Glu), Glutamine (Gln), Glycine (Gly), Histidine (His), Isoleucine (Ile), Leucine (Leu), Lysine (Lys), Proline (Pro), Serine (Ser), Threonine (Thr), Tryptophan (Trp) and Valine (Val) $\left(\right.$ Sigma $\left.^{\circledR}\right)$.

\subsection{Antioxidant enzymes activity}

Fresh leaf tissue (300 mg) was macerated in liquid nitrogen and then incubated with $50 \mathrm{mM}$ potassium phosphate buffer ( $\mathrm{pH} 7.0$ ), $0.05 \%$ triton, $10 \%$ polyvinyl polypyrrolidone (PVPP) and $1 \mathrm{Mm}$ acetylsalicylic acid (AsA). The solution obtained was centrifuged at $13.000 \mathrm{~g}$ at $4{ }^{\circ} \mathrm{C}$ for $30 \mathrm{~min}$ and the supernatant was stored at $-80^{\circ} \mathrm{C}$. SOD and APX activities were determined according to the method described by Reddy et al. (2004). CAT activity was analyzed according to Havir and McHale (1987).

\subsection{Growth analysis}

Shoot and root length, shoot and root dry weight, leaf area, leaf area ratio (LAR), relative growth rate (RGR) and net assimilation rate (NAR) were evaluated in 15 plants per treatment. Shoot length was measured from the insertion point of the last young leaf to the first branch of secondary root. For the root length was considered the whole portion located below the first branch of secondary root. The dry weight was obtained by drying the material in an oven at $65{ }^{\circ} \mathrm{C}$ for $72 \mathrm{~h}$ before weighing. Leaf area was measured from the images captured by the Digital Area Determiner (DDA) software.

\subsection{Stomatal density}

Stomatal density was determined by light microscopy of nail polish imprints. Leaves located in the third pair (apice from base) had their adaxial and abaxial surfaces imprinted and images were captured using microscope Olympus BX51 and DP controller software. The stomata were counted in a fixed area $\left(1 \mathrm{~mm}^{2}\right)$ in the apical, median and basal regions.

\subsection{Statistical analysis}

Data were subjected to the analysis of variance (Anova) and the averages were compared by Tukey's test $(p \leq 0.05)$. Pearson correlation coefficients between the environmental, physiological and biochemical parameters were evaluated and the significance of the correlations was tested by Student's t-test $(p \leq 0.05)$.

\section{Results}

\subsection{Water deficit decreased leaf turgescence}

The analysis of soil chemical composition detected acidity ( $\mathrm{pH}$ 4.34) and high levels of manganese, phosphorus, iron, aluminum and scarcity in boron. Physical analysis detected a porous soil with low capacity to retain significant amounts of water due to high levels of sand, clay and silt (Supplementary material 1). The average PPFD (photosynthetic photon flux density) was $194.88 \mu \mathrm{mol} \mathrm{m} \mathrm{m}^{-2}$ $\mathrm{s}^{-1}$ and the average air temperature oscillated with maximums at $35.5{ }^{\circ} \mathrm{C}$ and minimum at $14.1{ }^{\circ} \mathrm{C}$ during the experimental period. Relative humidity also varied with maximum values of $79 \%$ and minimum of $31 \%$. (Supplementary material 2 ).

Water deficit caused a decrease in the leaf relative water content (RWC) of Vatairea macrocarpa plants with values reaching $74.2 \%$ and $69.3 \%(50 \% \mathrm{fc})$ and $55.8 \%$ and $48.6 \%(25 \% \mathrm{fc})$ at 60 and 90 days respectively (Fig. 1). A decrease of $53.7 \%$ in RWC (25\% fc) at 90 days resulted in decreased turgescence and chlorosis mainly in the old leaves. After rehydration, RWC reached values similar to the control

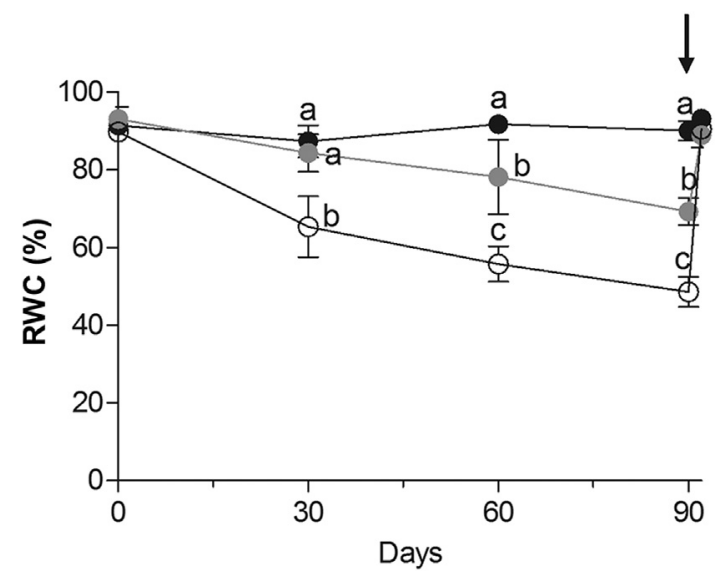

Fig. 1. Relative water content (RWC) in leaves of $V$. macrocarpa submitted to daily watering (control group - ), 50\% fc (O) and 25\% fc (O) during 92 days. Arrows indicate the day of resumption of irrigation. Different letters show significant difference between treatments at $P \leq 0.05(\mathrm{n}=15 \pm \mathrm{SD})$. 
plants, restoring the leaf turgescence.

\subsection{Rehydration induced the resumption of net carbon assimilation}

Gas exchange decreased significantly during the water deficit, showing a close relation with the availability of water in the soil. Photosynthetic rates of $V$. macrocarpa leaves decreased considerably reaching values of 4.58 and $3.64 \mu \mathrm{mol} \mathrm{m}^{-2} \mathrm{~s}^{-1}$ at 60 and 90 days for the $50 \%$ fc treatment. A more significant decrease was found from 60 days for the $25 \% \mathrm{fc}$ treatment with $1.51 \mu \mathrm{mol} \mathrm{m} \mathrm{m}^{-2}$ $\mathrm{s}^{-1}$, representing a reduction of $76.4 \%$ when compared to the control plants, whose photosynthetic rate was $6.75 \mu \mathrm{mol} \mathrm{m} \mathrm{m}^{-2} \mathrm{~s}^{-1}$ (Fig. 2A).

Transpiration rate decreased after 30 days of water restriction reaching the most significant values at 90 days (Fig. 2B) for both treatments $25 \% \mathrm{fc}\left(1.02 \mu \mathrm{mol} \mathrm{m}^{-2} \mathrm{~s}^{-1}\right)$ and $50 \% \mathrm{fc}\left(0.70 \mu \mathrm{mol} \mathrm{m} \mathrm{m}^{-2}\right.$ $\left.\mathrm{s}^{-1}\right)$. Stomatal closure promoted a significant reduction in stomatal conductance at 90 days, with values of $60.89 \mu \mathrm{mol} \mathrm{m}^{-2} \mathrm{~s}^{-1}$ (50\% fc) and $45.46 \mu \mathrm{mol} \mathrm{m}{ }^{-2} \mathrm{~s}^{-1}$ (25\% fc), which represent reductions of $36.2 \%$ and $52.37 \%$ when compared to the control plants (Fig. 2C). Transpiration rate and stomatal conductance became similar to the control plants after rehydration. The decrease in carbon assimilation was highly correlated with reductions in gas exchanges for both treatments $50 \%$ fc ( $A$ e $E: r=0.9, p=0.001$; $A$ e $g s: r=0.91$, $p=0,0009)$ and $25 \% \mathrm{fc}(A$ e $E: \mathrm{r}=0.94, p=0.0002 ;$ A e $g s: \mathrm{r}=0.95$, $p=0.0002$ ).

Similar result was observed for intercellular $\mathrm{CO}_{2}$ concentration (Ci), whose decrease was of $15 \%$ and $34 \%$ for the $50 \%$ and $25 \% \mathrm{fc}$, respectively, when compared to the control treatment at 90 days (Fig. 2D). Water use efficiency (WUE) was significantly reduced under water stress showing values of $20.7(50 \% \mathrm{fc})$ and $17.1 \mu \mathrm{mol} \mathrm{mol}^{-1}$ (25\% fc) at 90 days (Fig. 2E). After rehydration there was a resumption of net carbon assimilation in plants under water stress. High correlation was observed between $A$ and WUE (50\% fc: $\mathrm{r}=0.8, p=0.009$; and 25\% fc: $\mathrm{r}=0.97, p=0.00003$ ).

\subsection{Water deficit changed the leaf pigment content}

The total chlorophyll content decreased significantly from 60 days for the $25 \%$ fc treatment, reaching more significant values at 90 days for both treatments. A decrease of $47 \%$ in chlorophyll $a$ and $38.7 \%$ in chlorophyll $b$ was observed at the end of 90 days for the $25 \%$ fc treatment (Fig. 3A, B, C). After rehydration (48 h later), the synthesis of new chlorophylls occurred rapidly, reaching values similar to the control plants. Positive correlation between the reduction in carbon assimilation and chlorophyll content was observed for the $25 \%$ fc treatment. $r=0.89, p=0.001$ and $r=0.88$, $p=0.001$.
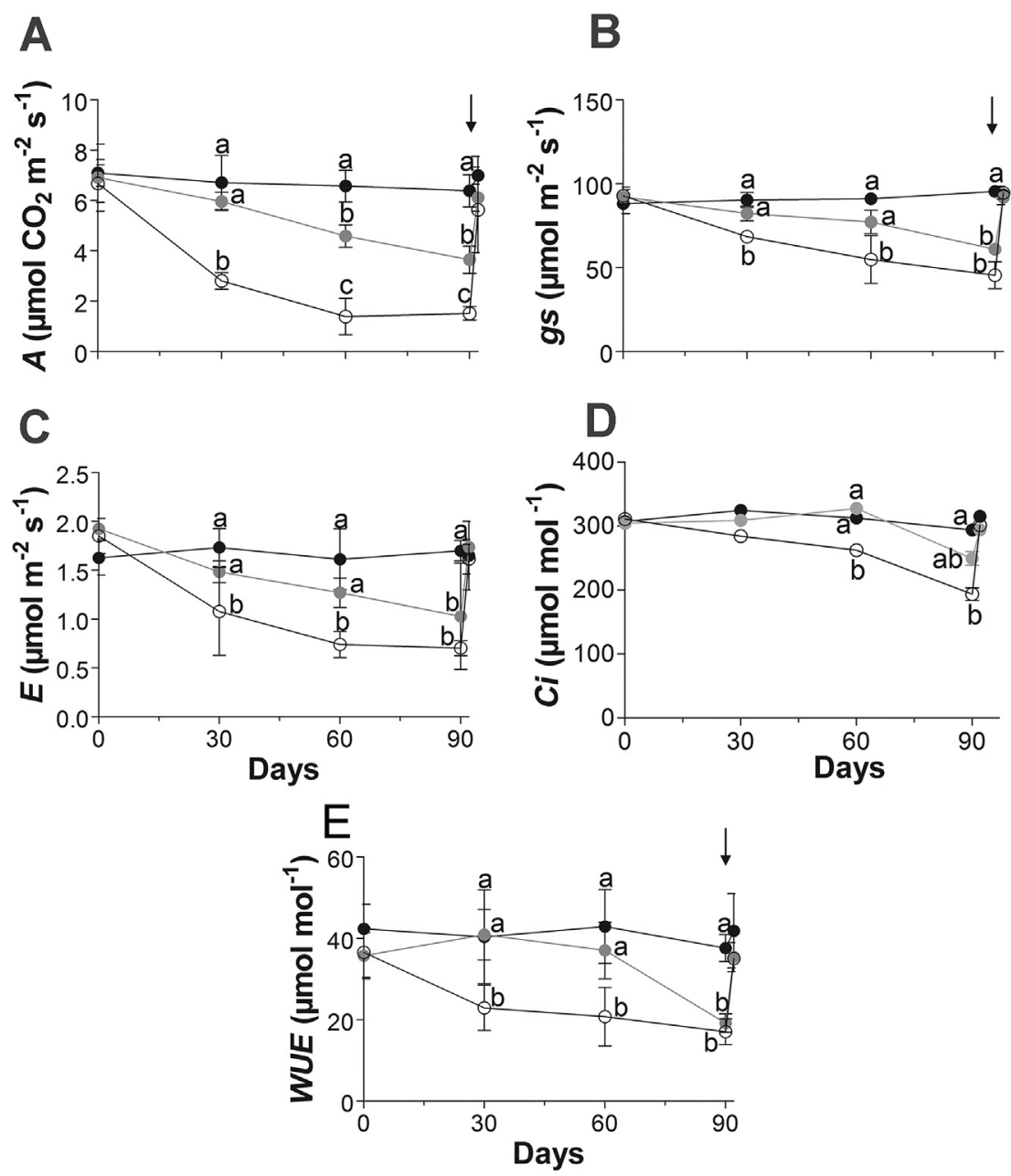

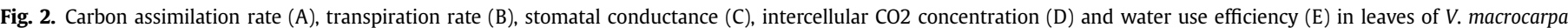

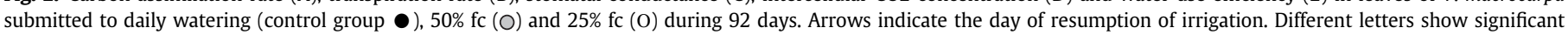
difference between treatments at $P \leq 0.05(\mathrm{n}=15 \pm \mathrm{SD})$. 

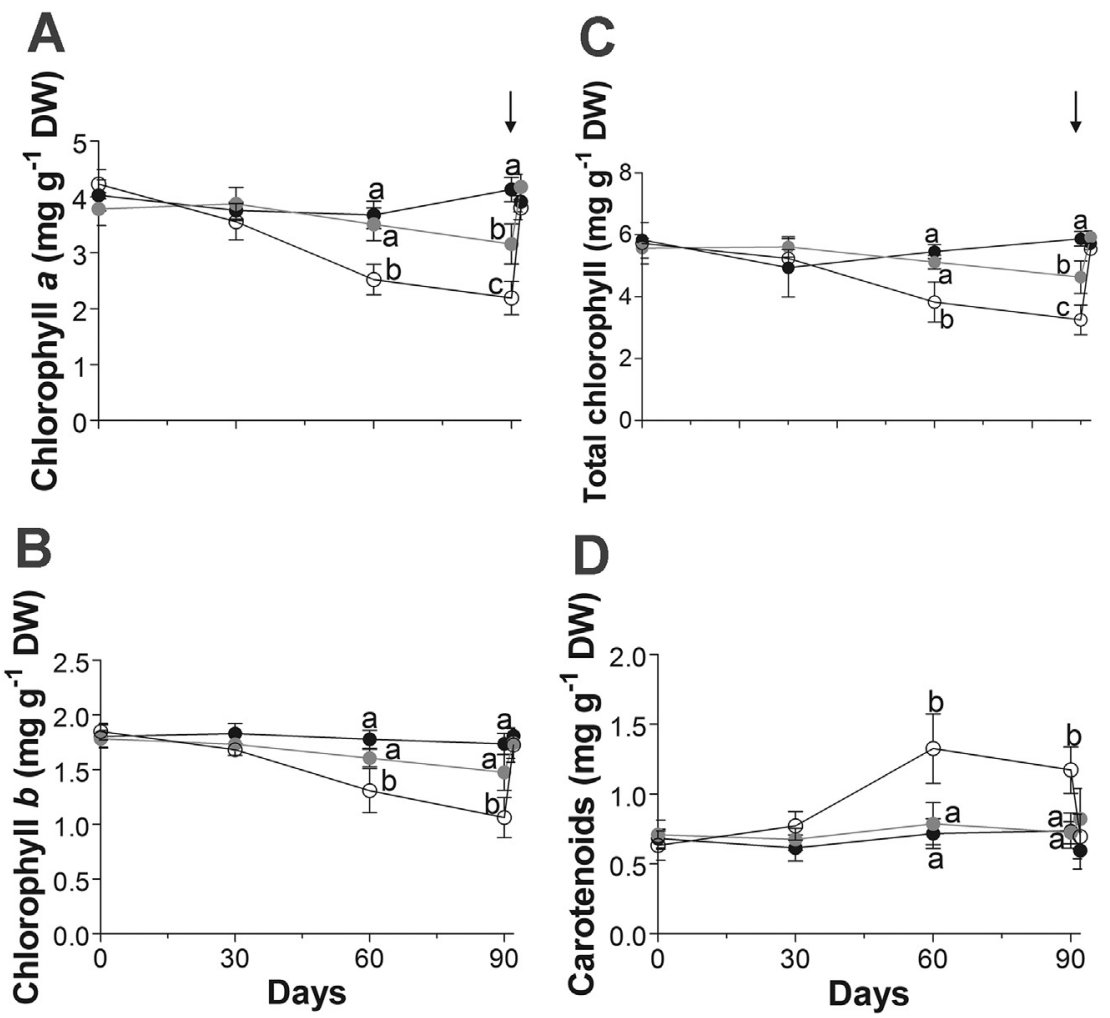

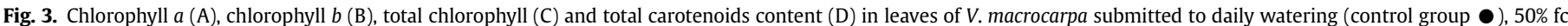

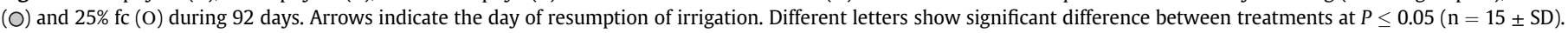

In contrast, the amount of total carotenoids increased significantly from 30 days for the $25 \%$ fc treatment, with maximum values of $1.11 \mathrm{mg} \mathrm{g}^{-1} \mathrm{DW}$ (increment of 34.2\%) (Fig. 3D). Negative correlation between carotenoid and chlorophyll content was observed for the $25 \%$ fc treatment (Chloro $a$ : $\mathrm{r}=-0.91, p=0.0007$ e Chloro $b$ : $r=-0.92, p=0.0006)$. No significant difference in carotenoid content was observed for the $50 \% \mathrm{fc}$ treatment. The total carotenoid content was recovered $48 \mathrm{~h}$ after rehydration, as observed for chlorophylls.

\subsection{Increase in non-structural carbohydrates contributed to the osmotic adjustment}

The water availability also influenced the total soluble carbohydrate content from the $V$. macrocarpa leaves. A gradual decrease in RWC ( $50 \% \mathrm{fc}$ ) resulted in about $26.4 \%$ more sugars at the end of 90 days. However, when RWC decreased considerably (25\% fc) an increase of $35.2 \%$ in the sugars content was observed in this same period (Fig. 4A). Quantitative analyzes by HPAEC/PAD detected glucose, fructose, sucrose and raffinose as the main soluble sugars. No significant differences were found in glucose and fructose content (Fig. 4B and C).

A significant increase in sucrose content occurred from 60 days for the $25 \%$ fc treatment and at 90 days for the $50 \%$ fc treatment. However, more significant differences were detected in plants submitted to intense water deficit ( $25 \% \mathrm{fc}$ ) at 90 days, presenting an increase of $42.4 \%$ in the sucrose content when compared to the control plant (Fig. 4D). Raffinose content increased significantly from 60 days only for the $25 \%$ fc treatment (Fig. 4E), reaching about $48.5 \%$ more raffinose at 90 days. A significant decrease in leaf starch content was observed only in plants submitted to $25 \%$ fc treatment, presenting a reduction of $48 \%\left(22 \mathrm{mg} \mathrm{g}^{-1} \mathrm{DW}\right)$ in the starch content when compared to the control plant at 90 days (Fig. 4F). After rehydration, the sugar content was recovered and the starch content increased, although not statistically significant.

Negative correlations were observed between $A$ and total carbohydrate (50\% fc: $\mathrm{r}=-0.71, p=0.03$ and $25 \% \mathrm{fc}: \mathrm{r}=-0.82$ $p=0.007) A$ and sucrose (50\% fc: $\mathrm{r}=-0.81, p=0.008$ and $25 \% \mathrm{fc}$ : $\mathrm{r}=-0.8, p=0.01) A$ and raffinose content $(25 \% \mathrm{fc}: \mathrm{r}=-0.8$ $p=0.009)$. Negative correlation was also detected between starch and total carbohydrate $(\mathrm{r}=-0.8, p=0.01)$, starch and sucrose $(\mathrm{r}=-0.82, p=0.007)$, starch and raffinose $(\mathrm{r}=-0.83, p=0.006)$ for the $25 \% \mathrm{fc}$ treatment. In contrast, a high correlation was observed between total carbohydrate and sucrose ( $50 \% \mathrm{fc}: \mathrm{r}=0.74$, $p=0.02$ and $25 \% \mathrm{fc}: \mathrm{r}=0.95, p=0.0002)$ total carbohydrate and raffinose (25\% fc: $\mathrm{r}=0.93, p=0.0005)$ and sucrose and raffinose content (25\% fc: $r=0.93, p=0.0004)$.

\subsection{Water deficit induced changes in the amino acids profile}

The most representative free amino acids of the hydrated leaves of V. macrocarpa were Gln, Asn, Asp, Arg, Ala and Pro, which constitute approximately $80 \%$ of the total free amino acids (Fig. 5). Both treatments induced an increase in the amino acid levels at 90 days as follows: Gln with $32 \%$ (50\% fc) and $47.5 \%$ (25\% fc) (Fig. $5 \mathrm{~A}$ ); Pro with $64.4 \%$ (50\% fc) and $81.1 \%$ (25\% fc) (Fig. 5I). For the $25 \%$ fc treatment, Val and Trp increased significantly from 60 days reaching values of $73.7 \%$ and $70.9 \%$, respectively (Fig. 5D, K). Ser and GABA presented higher content after 30 days of water stress (Fig. 5G, N). Positive correlations between Gln and Pro (25\% fc: $\mathrm{r}=0.92, p=0.0006)$, Gln and Val (25\% fc: $\mathrm{r}=0.87, p=0.002)$, Gln and $\operatorname{Trp}(25 \% \mathrm{fc}: \mathrm{r}=0.92, p=0.0007)$, Pro and Val (50\% fc: $\mathrm{r}=0.75$, $p=0.019$ and $25 \% \mathrm{fc}: \mathrm{r}=0.94, p=0.0002)$, Pro and $\operatorname{Trp}(50 \% \mathrm{fc}$ : $\mathrm{r}=0.83, p=0.006$ and $25 \% \mathrm{fc}: \mathrm{r}=0.91, p=0.0007)$ were observed. 


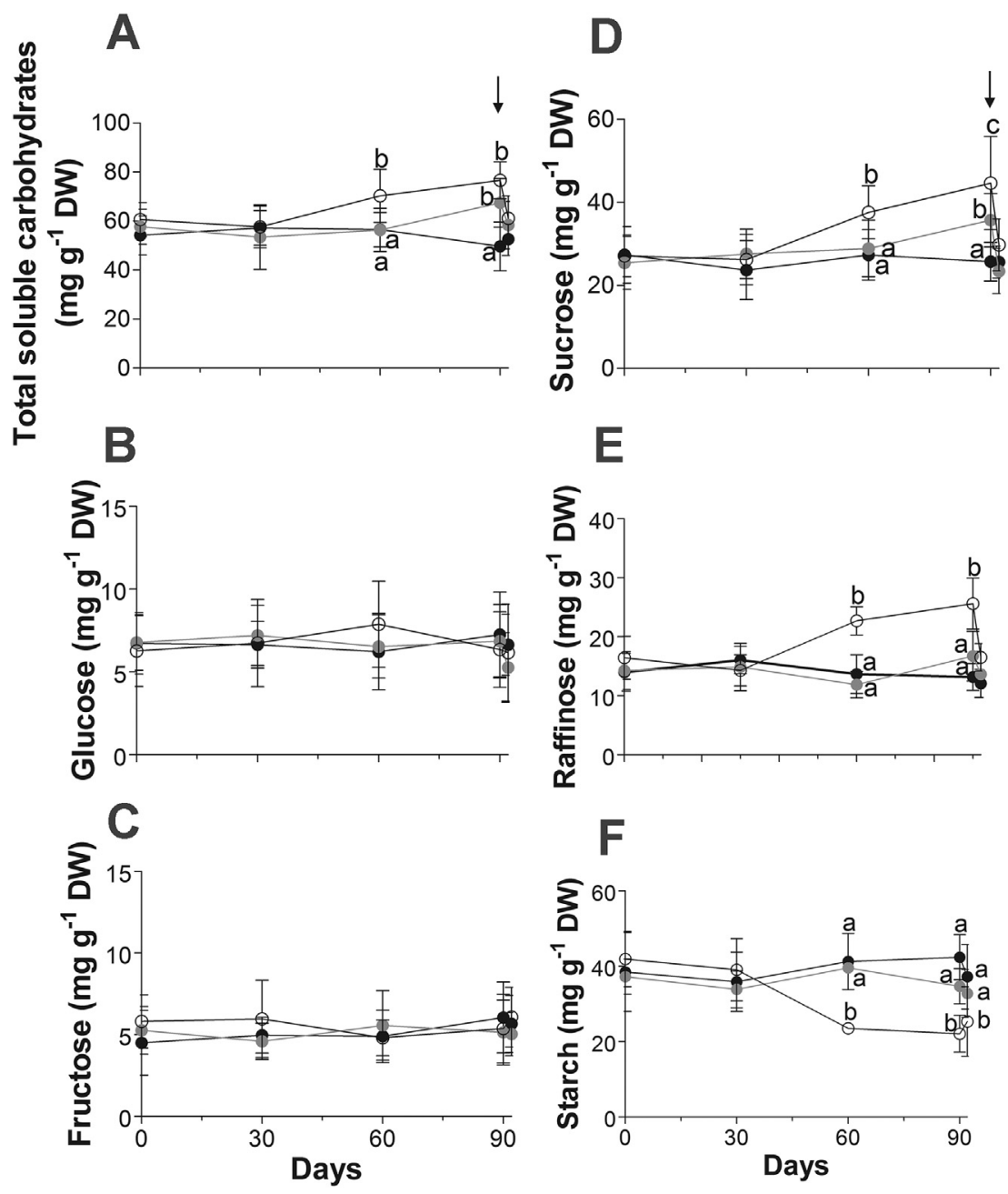

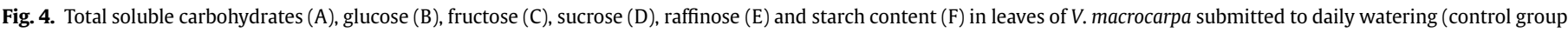

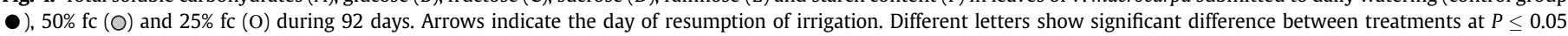
$(\mathrm{n}=15 \pm \mathrm{SD})$.

In contrast, water stress significantly decreased the content of Asp (64.9\%) and Asn (50.8\%) at 90 days for the 25\% fc treatment $(\mathrm{r}=0.73, p=0.02$ ) (Fig. H). Positive correlations were observed between $A$ and Asp $(r=0.88, p=0.002), A$ and Asn $(r=0.81$, $p=0.008$ ) only for the $25 \%$ fc treatment. No significant differences were observed for the levels of Arg, Gly, Thre, Ala, Leu, Lys (Fig. 5C, $\mathrm{E}, \mathrm{F}, \mathrm{J}, \mathrm{L}, \mathrm{M}$ ) and other amino acids detected in very low amounts. Most of the amino acids studied had their content recovered $48 \mathrm{~h}$ after rehydration.

\subsection{Water deficit improved the antioxidant activity}

The treatments of water restriction improved the antioxidant activities of SOD, CAT, and APX. SOD activity increased $19.8 \%$ for the $50 \%$ fc treatment at 90 days and $27.9 \%$ for the $25 \%$ fc treatment at 60 days (Fig. 6A). CAT activity improved about $48.6 \%$ at 60 days and $64 \%$ at 90 days only for the $25 \%$ fc treatment (Fig. 6 B). APX activity increased $60.9 \%$ at 60 days and $59.3 \%$ at 90 days for the $25 \% \mathrm{fc}$ treatment whereas an increase of $70 \%$ was observed in plants submitted to $50 \% \mathrm{fc}$ treatment at 90 days (Fig. 6C). After rehydration, SOD, CAT and APX activities became similar to those of the control plant.

Negative correlations were observed between $A$ and SOD $(\mathrm{r}=-0.75, p=0.02), A$ and CAT $(\mathrm{r}=-0.8, p=0.01), A$ and APX
( $\mathrm{r}=-0.9, p=0.001)$ for the $25 \% \mathrm{fc}$ treatment. Positive correlations were detected between SOD and CAT ( $25 \% \mathrm{fc}: \mathrm{r}=0.72, p=0.02$ ), SOD and APX (50\% fc: $r=0.79, p=0.01$ and $25 \% \mathrm{fc:} r=0.91$, $p=0.0008)$ and CAT and APX (25\% fc: $\mathrm{r}=0.91, p=0.0008)$.

\subsection{The decrease in carbon assimilation affected the growth}

A significant decrease in shoot length $(24.1 \mathrm{~cm})$ was observed only in plants submitted to $25 \% \mathrm{fc}$ (Fig. $7 \mathrm{~A}$ ). No significant differences were found for the $50 \% \mathrm{fc}$ treatment $(32.2 \mathrm{~cm})$, whose values were similar to those of the control plant $(34.8 \mathrm{~cm})$. By contrast, a significant increase in root length was observed after 30 days of water restriction for both treatments (Fig. 7B). Shoot dry weight decreased significantly at 90 days only in the plants submitted to $25 \%$ fc treatment ( $2.6 \mathrm{~g}$ ) when compared to the control group ( $4.1 \mathrm{~g}$ ) (Fig. 7C). Similar result was observed for root dry weight, which showed significant reductions in plants submitted to $25 \%$ fc treatment ( $4.2 \mathrm{~g}$ ) (Fig. 7D). The severe water deficit (25\% fc) reduced the leaf area at 30 and 60 days, although not statistically significant in relation to the control group (Fig. 7E). Similar results were observed for LAR values (Fig. 7F), suggesting correlation between the reduction of the leaf area and dry mass.

Water stress decreased NAR values between 30 and 60 days for the $25 \%$ fc treatment. However, significant differences for both 

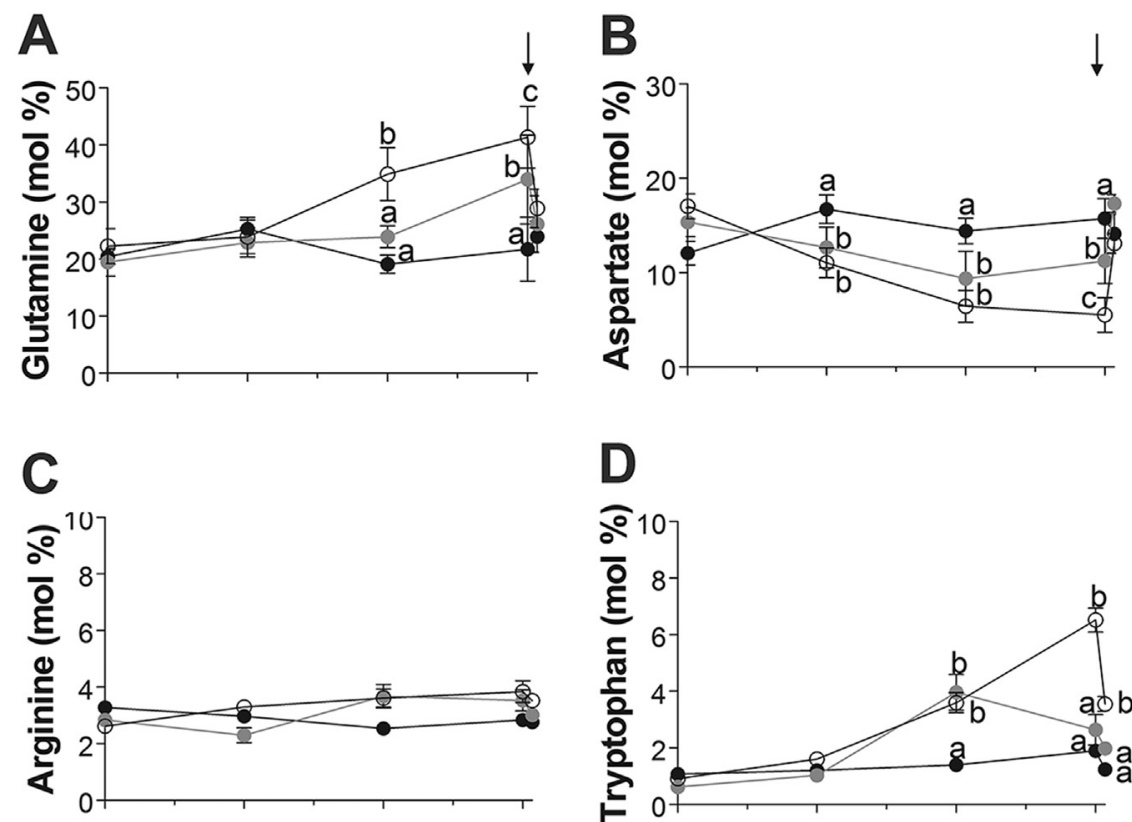

D

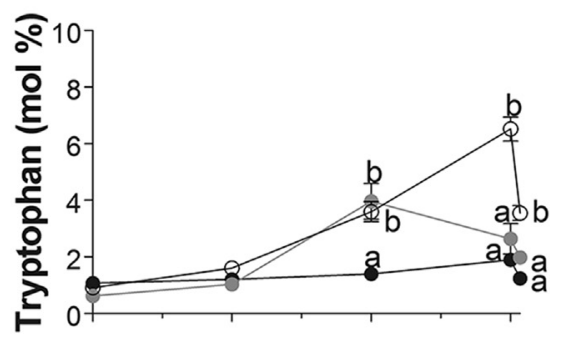

E
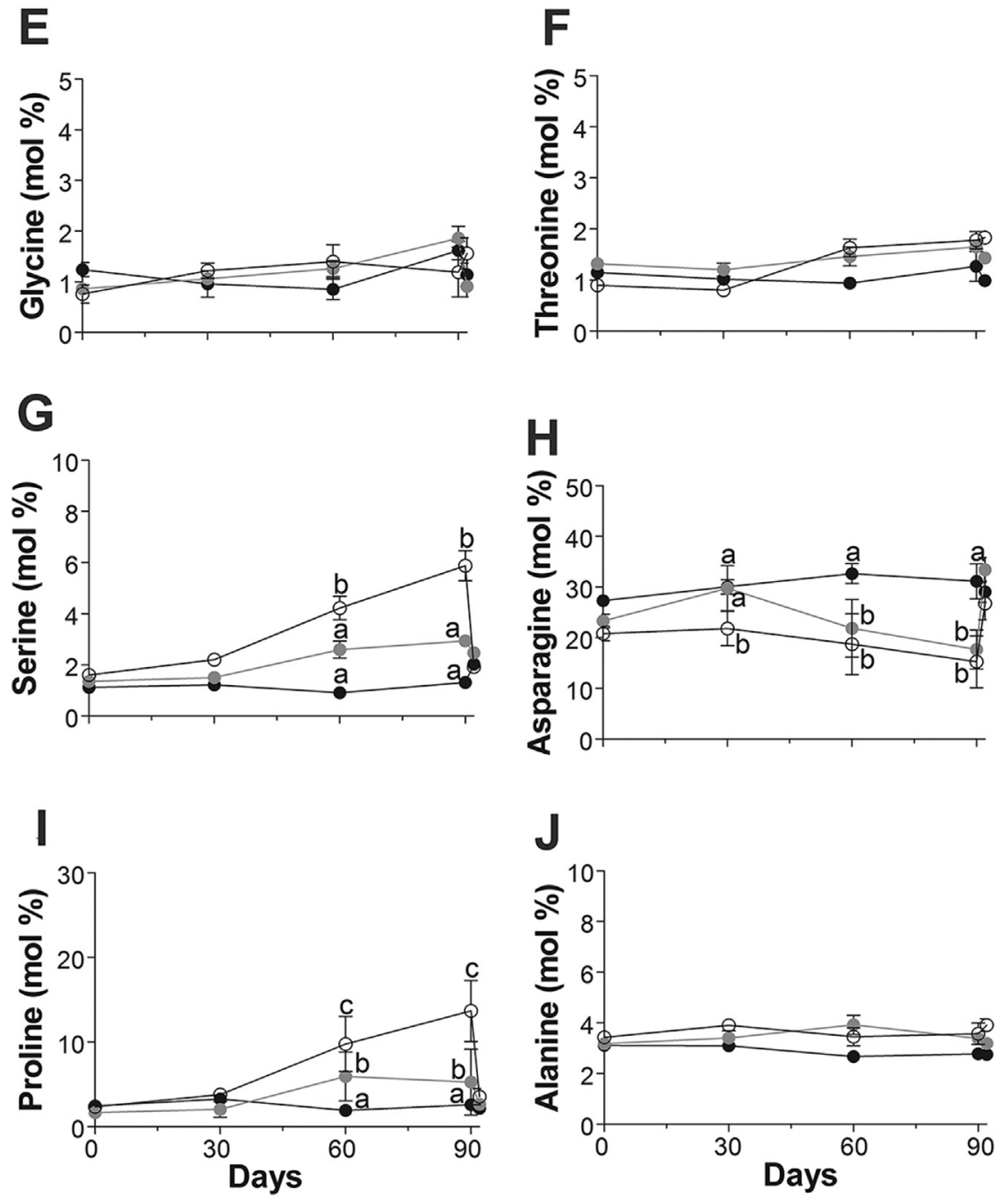

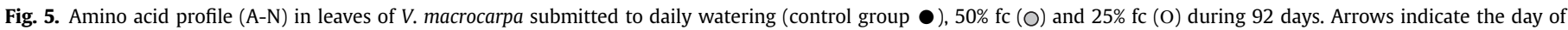
resumption of irrigation. Different letters show significant difference between treatments at $P \leq 0.05(\mathrm{n}=15 \pm \mathrm{SD})$. 

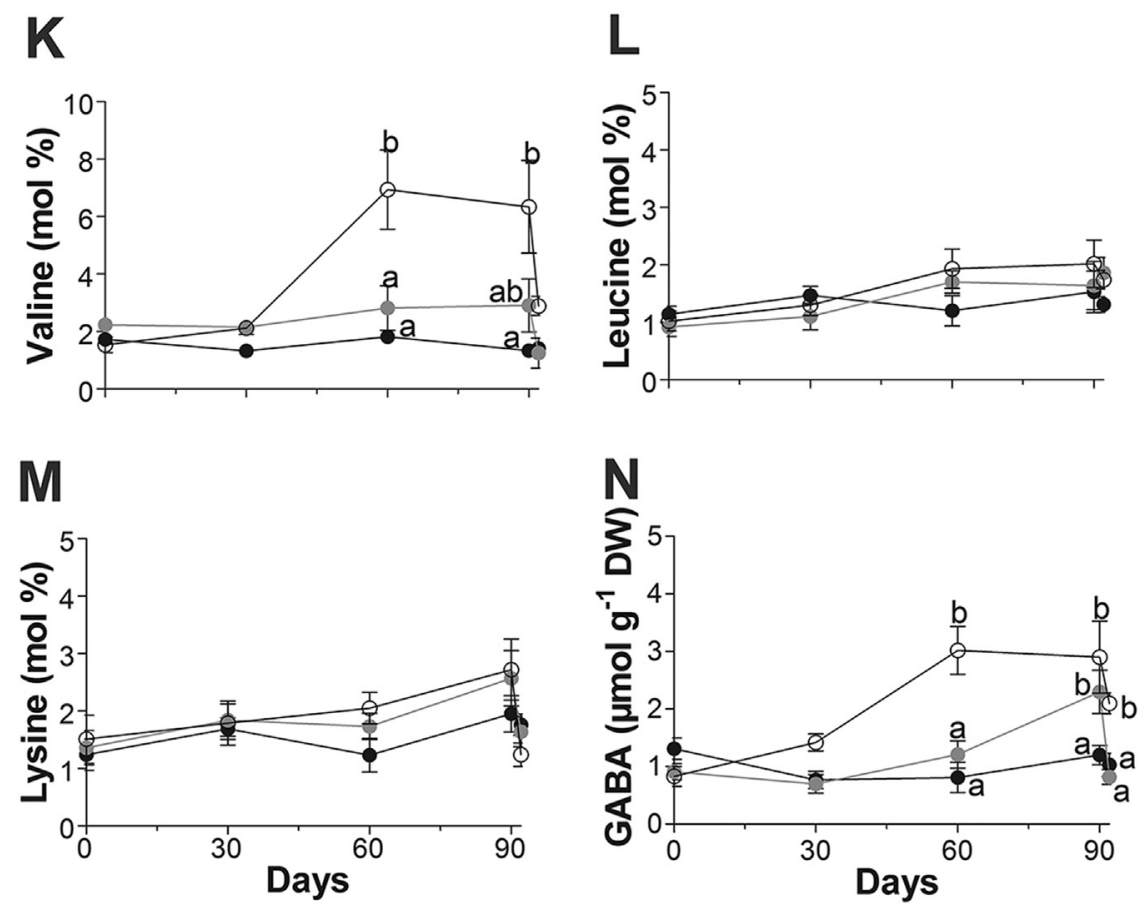

Fig. 5. (continued).

treatments were observed only between 60 and 90 days resulting in significant reduction in the plant growth (Fig. 7G). Similar results were observed for RGR, which showed significant values between 30 and 60 days concomitantly with the decrease of RWC in the same period, especially for plants submitted to $25 \% \mathrm{fc}$ (Fig. $7 \mathrm{H}$ ).

\subsection{Water deficit increased the amount of stomata}

Young leaves showed a greater number of paracytic stomata on the abaxial surface in the three analyzed regions, varying from 301.5 to 426.1 stomata per $\mathrm{mm}^{2}$ (Supplementary material 3). Water stress induced an increase in the number of stomata in the apical (14.12\%) and median (16.44\%) region of the leaf only for the $25 \% \mathrm{fc}$ treatment (Table 1). The lowest values were observed in the basal region for all treatments. On the adaxial surface, 1 or 2 stomata per $\mathrm{mm}^{2}$ were observed sporadically.

\section{Discussion}

Young plants of Vatairea macrocarpa presented resistance to the imposed water deficit, ensuring sufficient RWC values to allow the activity of the assimilatory apparatus. Although RWC decreased significantly during the 90 days of water restriction in both treatments, photochemical activities were maintained satisfactorily without significant metabolic damage. Instead, a set of strategies to prevent water loss from the leaves was implemented.

The low transpiration rate observed in $V$. macrocarpa plants under water deficit decreased WUE values. The amount of $\mathrm{CO}_{2}$ used in photosynthesis and the opening time of the stomata are directly related to high evaporation rates. In fact, water stress induced stomatal limitations as observed by low values of gs and $\mathrm{Ci}$ that in turn decreased the carbon assimilation from 30 days. This observation supports the interpretation that the principal limitation of photosynthesis occurs through stomatal effects, as suggested by Zivcak et al. (2013). Stomatal closure may prevent the $\mathrm{CO}_{2}$ diffusion to the Rubisco catalytic site, leading to a decrease in $A$ and therefore in reduced carbon assimilation (Lawlor and Cornic, 2002). In addition, another relevant consideration on the efficiency of gas exchange in plants under drought is the mesophyll limitation $\left(g_{m}\right)$. According to Flexas et al. (2012), the acclimation of $g_{m}$ during extended drought periods represents an effective way of optimizing $\mathrm{CO}_{2}$ diffusion transiently under limited $\mathrm{CO}_{2}$ source, contributing to the adjustment of the plants during and after stress.

The high stomatal density observed in plants submitted to $25 \%$ fc may have been a strategy to compensate the stomatal closure and then promote homeostasis in gas exchange. Indeed, plants under water deficit present changes in the stomata density and size to improve gas exchange during drought (Zhao et al., 2015). Yang et al. (2007) showed positive relation between high stomatal density and WUE. Recently, Tanaka et al. (2013) showed an improvement in gas diffusion and photosynthetic rate in plants with high stomatal density. Although gs and WUE have not increased during the 90 days of water restriction, these parameters remained constant (not statistically significant) throughout the period of severe water stress $(25 \% \mathrm{fc})$. Furthermore, the high correlation between the decrease in the chlorophyll content and gs observed in the final periods of severe water stress $(25 \% \mathrm{fc})$ was not enough to compromise $A$. These findings support our hypothesis that $V$. macrocarpa presents an efficient adjustment of the assimilatory apparatus and a great capacity for acclimatization during the drought.

The increase in carotenoid content observed from 30 days of severe water stress $(25 \% \mathrm{fc}$ ) probably is related to the absorption of excessive light to avoid photoxidative damage to PSII (Deng et al., 2003). In addition, $V$. macrocarpa plants presented improved activities of APX, CAT and SOD after 60 days of water stress, which play an important role in removing ROS excess. These findings confirm the observations previously reported by Yang et al. (2009), as they showed improvement of CAT, SOD, POD, APX and GR activities and an increase in carotenoids content in Populus cathayana and $P$. kangdingensis plants under severe water deficit (25\% fc). Besides ROS detoxification systems, others strategies are 

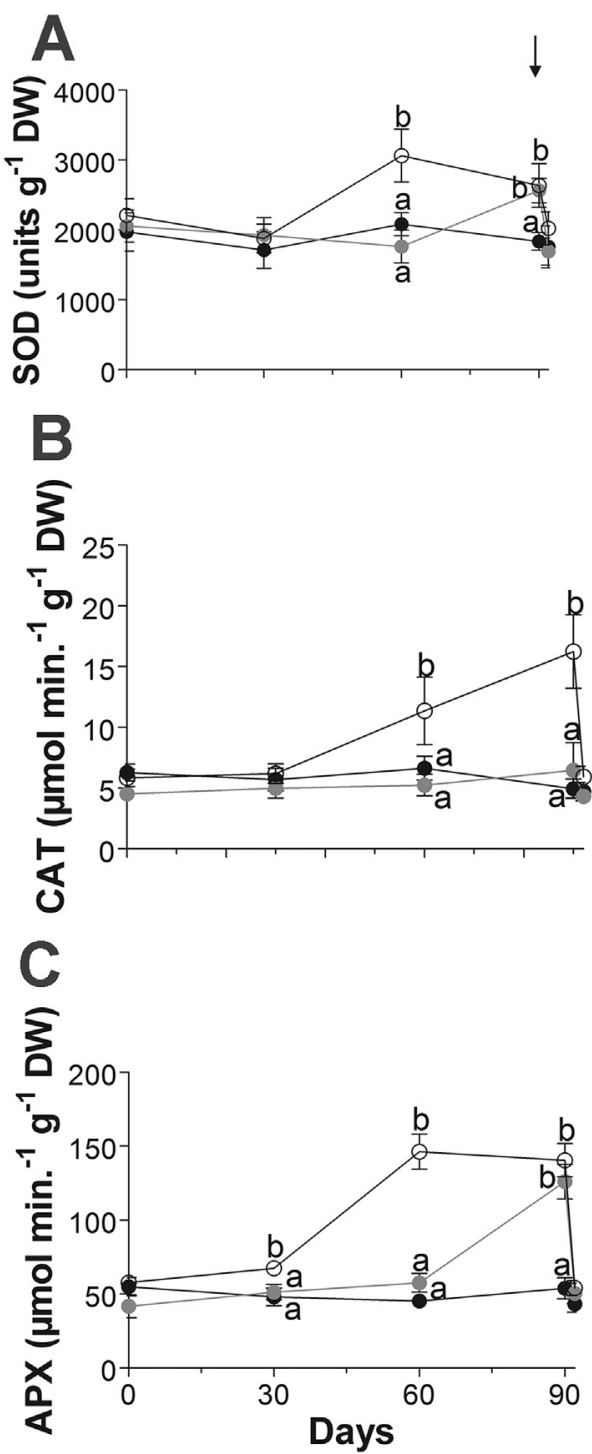

Fig. 6. Antioxidant activity of SOD (A), CAT (B) and APX (C) in leaves of V. macrocarpa submitted to daily watering (control group - ), 50\% fc (O) and 25\% fc (O) during 92 days. Arrows indicate the day of resumption of irrigation. Different letters show significant difference between treatments at $P \leq 0.05(\mathrm{n}=15 \pm \mathrm{SD})$.

essential for plant tolerance to drought. These strategies involve the reduction in the synthesis of chlorophylls and other components of the assimilatory apparatus, as well as the balance in the sugar metabolism, since sucrose glycolytic pathway feeds the oxidative pentose-phosphate pathway (Petrov et al., 2015).

The strong negative correlation demonstrated between the increase in carbohydrate content and decrease of $A$ indicates that the water restriction promoted adjustments in the carbon metabolism. The significant increase of sucrose, raffinose and total soluble carbohydrates in the final stages of the severe water deficit ( $25 \% \mathrm{fc}$ ) occurred simultaneously with the starch degradation. Soluble sugars act as signaling molecules and interact with membrane and cytosol macromolecules preventing water loss (Stitt et al., 2010). These results suggest that in drought conditions, $V$. macrocarpa plants have an osmotic adjustment mechanism in which starch is degraded in soluble sugars. This hypothesis is consistent with a previous study carried out with seedlings of Hymenaea stignocarpa, Dalbergia miscolobium and Jacaranda ulei, among others Cerrado species, whose increase in non-structural sugars was important to tolerate the water deficit in the periods of seasonal drought when compared to forest species (Hoffmann et al., 2004).

$V$. macrocarpa plants submitted to water stress for 60 days, besides showing a significant increase in the Pro and Try contents in both treatments, also showed an increase in Glu, Val, Ser and GABA for the treatment $25 \% \mathrm{fc}$. These changes contribute to the cellular osmotic adjustment and also are related to the storage of carbon and nitrogen sources for a new synthesis of organic material after rehydration (Aranjuelo et al., 2011). Garcia et al. (2015) showed that in Chrysolaena obovata, a Cerrado specie, Pro content increased during periods of drought and decreased after rehydration. Decreases in Asn and Asp content are related to nitrogen metabolism while the relation between Asn and Gln is associated with carbon and nitrogen metabolism (Lam et al., 1996). High levels of light and carbohydrates stimulate Gln synthesis and inhibit Asn synthesis. This antagonistic regulation maintains equilibrium between the carbon and nitrogen metabolism, favoring the assimilation of nitrogen into Gln, which is rich in carbon and participates in the synthesis of new plant tissues (Lam et al., 1996). Curiously, $V$. macrocarpa plants showed a strong positive correlation between soluble carbohydrates and Gln after 60 days of water stress, and also a significant decrease in Asp and Asn content. Taken together, these findings suggest that, Gln synthesis appears to occur through a carbohydrate-mediated signaling pathway and that Gln rather than Asp or Asn is used as a carbon source by V. macrocarpa plants under drought.

Although the metabolic strategies minimize the effects of drought, they are often not enough to avoid the degradation of pigments, proteins and carbohydrates (Aranjuelo et al., 2011). In desiccation-tolerant plants, pigment degradation followed by accumulation of nitrogen metabolites suggests nitrogen relocation for the synthesis of osmoregulatory amino acids (Oliver et al., 2011). Thus, the observed increase in Gln content may also be due to the degradation of nitrogen compounds (proteins and pigments), playing an important role as a source of nitrogen to supply the metabolic demand after rehydration. This hypothesis is supported by the Glu content reaching values similar to the control group after rehydration.

In plants, GABA accumulation occurs under various types of stress (Bown and Shelp, 2016). Mekonnen et al. (2016) demonstrated that mutants of Arabidopsis thaliana deficient for GABA production and submitted to water stress withered before the wild type. These autors showed that GABA plays an important role in inducing stomatal closure and preventing water loss. In this work, plants under drought presented a strong negative correlation between the increase in GABA content and decrease in stomatal conductance. These findings indicate that GABA production was one of the strategies used by $V$. macrocarpa plants to alleviate the effects of drought, preventing water loss.

GABA accumulation affects cell wall elongation in vegetative and reproductive tissues (Renault et al., 2011). Indeed, the increase in leaf GABA content coincided with the drastic reduction in the shoot length during the drought. The shoot elongation depends on the availability of carbon and leaf expansion rate, which in turn are dependent on the balance among net photosynthesis, starch accumulation, and the incorporation of compounds containing carbon (organic acids) in the metabolism (Muller et al., 2011). Thus, GABA accumulation may be a signaling to decrease the carbon demand (growth) before the supply (photosynthesis) is affected by the water restriction. In the control plants, the highest shoot length and biomass allocation are related to higher net assimilation rates and starch storage in the leaves, suggesting a trade-off between expansion and storage during the day.

The water deficit decreased the leaf area, which was determinant to decrease LAR. The observed reduction in leaf area for the 

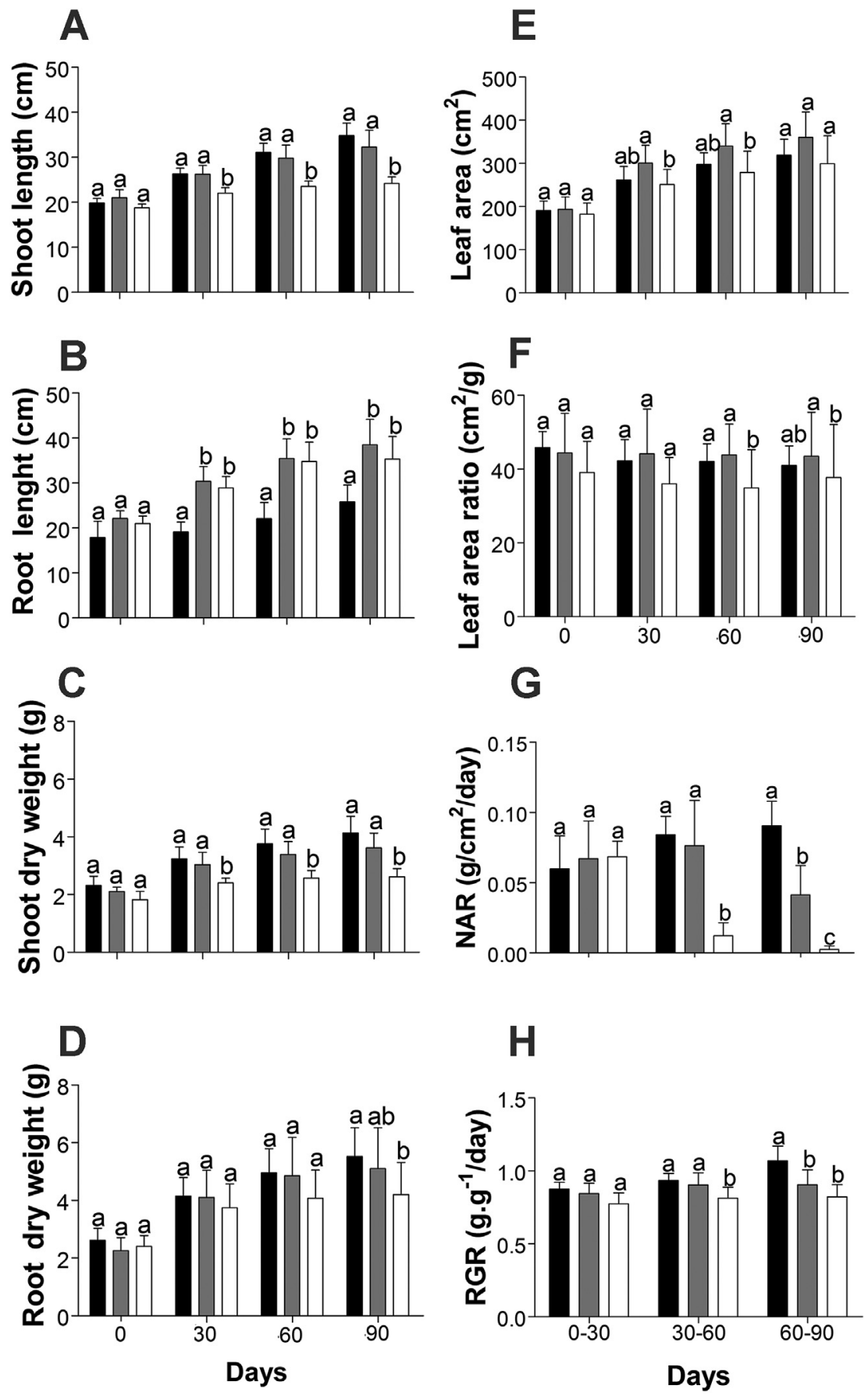

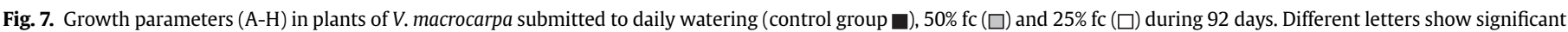
difference between treatments at $P \leq 0.05(\mathrm{n}=15 \pm \mathrm{SD})$.

Table 1

Stomatal density $\left(\mathrm{mm}^{2}\right)$ in the apical, median and basal regions of the leaves of $V$. macrocarpa under water deficit $(\mathrm{n}=15)$.

\begin{tabular}{|c|c|c|c|c|c|c|c|c|c|}
\hline \multirow{2}{*}{$\frac{\text { Leaf Parts }}{\text { Treatments }}$} & \multicolumn{3}{|l|}{ Apical } & \multicolumn{3}{|l|}{ Median } & \multicolumn{3}{|l|}{ Basal } \\
\hline & Mean & & SD & Mean & & SD & Mean & & SD \\
\hline Control & $359,8 a^{*}$ & \pm & 32,3 & $376,1 \mathrm{a}$ & \pm & 30,1 & $301,5 a$ & \pm & 33,2 \\
\hline $50 \%$ fc & $370,3 a$ & \pm & 21,3 & $382,4 a$ & \pm & 26,2 & $316,6 a$ & \pm & 24,3 \\
\hline $25 \% \mathrm{fc}$ & $418,7 b$ & \pm & 56,9 & $426,1 \mathrm{~b}$ & \pm & 42,3 & $321,0 a$ & \pm & 49,7 \\
\hline
\end{tabular}

*Means followed by different letters in the columns differ by Tukey test at $\mathrm{P} \leq 0.05$. treatment $25 \% \mathrm{fc}$ occurred at the same time to the increase in the root surface area, suggesting carbon allocation to the roots. Savannah species generally present greater investment in roots with a high root/shoot ratio to improve resource acquisition (Dalmolin et al., 2015). Moreover, the decrease of the leaf area was an important strategy to reduce the transpiration surface, maintaining the water status of the whole plant. In $V$. macrocarpa plants, decreases in photosynthetic rates reduced the demand for assimilates to the growing organs, resulting in a significant decrease in dry mass production, as observed by NAR values between 60 and 90 days. As a consequence, shoot growth was inhibited mainly in 
plants submitted to $25 \%$ fc treatment, as observed by RGR values.

\section{Conclusion}

Overall, our results demonstred that the physiological and biochemical responses of $V$. macrocarpa plants to the different levels of water deficit were not compromised, but were adjusted so that new homeostatic states were reached. Physiological and biochemical changes attenuated the effects of drought and maintained the assimilatory metabolism at minimum levels, allowing its resumption after rehydration. Thus, the metabolic changes observed in response to water restriction point to the resistance of $V$. macrocarpa to drought and in the future may be used in conservation program of areas subjected to extended period of drought, such as Cerrado.

\section{Funding}

This work was fully supported by the Universidade Estadual de Mato Grosso do Sul-UEMS.

\section{Conflict of interest statement}

The authors declare that there are no conflicts of interest regarding this manuscript.

\section{Contributions}

E. Vieira and M. Silva performed the experiments. E. Vieira, M. Silva, C. Moro and V. Laura designed the research, contributed to the data interpretation, discussion and paper writing. All authors reviewed and approved the final version of the manuscript.

\section{Acknowledgments}

We thank Marcio Tomaz de Assis for his technical assistance. We thank Laboratório Solos Campo Grande-MS for soil analysis.

\section{Appendix A. Supplementary data}

Supplementary data related to this article can be found at http:// dx.doi.org/10.1016/j.plaphy.2017.04.022.

\section{References}

Apel, K., Hirt, H., 2004. Reactive oxygen species: metabolism, oxidative stress, and signal transduction. Annu. Rev. Plant Biol. 55, 373-399. http://dx.doi.org/ 10.1146/annurev.arplant.55.031903.141701.

Aranjuelo, I., Molero, G., Erice, G., Avice, J.C., Nogués, S., 2011. Plant physiology and proteomics reveals the leaf response to drought in alfalfa (Medicago sativa L.). J. Exp. Bot. 62, 11-23. http://dx.doi.org/10.1093/jxb/erq249.

Ashraf, M., Foolad, M.R., 2007. Roles of glycine, betaine and proline in improving plant abiotic stress resistance. Environ. Exp. Bot. 59, 206-216. http://dx.doi.org/ 10.1016/j.envexpbot.2005.12.006.

Assaha, D.V., Liu, L., Ueda, A., Nagaoka, T., Saneoka, H., 2016. Effects of drought stress on growth, solute accumulation and membrane stability of leafy vegetable, huckleberry (Solanum scabrum Mill.). J. Environ. Biol. 37, 107-114.

Ball, A., Sanchez-Azofeifa, A., Portillo-Quintero, C., Rivard, B., Castro-Contreras, S., Fernandes, G., 2015. Patterns of leaf biochemical and structural properties of cerrado life forms: implications for remote sensing. PLoS One 18. http:// dx.doi.org/10.1371/journal.pone.0117659.

Bown, A.W., Shelp, B.J., 2016. Plant GABA: not just a metabolite. Trends Plant Sci. 21, 811-813. http://dx.doi.org/10.1016/j.tplants.2016.08.001.

Caccere, R., Teixeira, S.P., Centeno, D.C., Figueiredo-Ribeiro, R.C.L., Braga, M.R., 2013. Metabolic and structural changes during early maturation of Inga vera seeds are consistent with the lack of a desiccation phase. J Plant Physiol 170 (9), 791-800. http://dx.doi.org/10.1016/j.jplph.2013.01.002.

Carvalho, F., Souza, F.A., Carrenho, R., Moreira, F.M.S., Jesus, E.C., Fernandes, G.W. 2012. The mosaic of habitats in the high-altitude Brazilian rupestrian fields is a hotspot for arbuscular mycorrhizal fungi. Appl. Soil Ecol. 52, 9-19. http://dx.doi. org/10.1016/j.apsoil.2011.10.001.
Dalmolin, A.C., Lobo, F.A., Vourlitis, G., Silva, P.R., Dalmagro, H.J., Antunes Jr., M.Z. Ortíz, C.E.R., 2015. Is the dry season an important driver of phenology and growth for two Brazilian savanna tree species with contrasting leaf habits? Plant Ecol. 216, 407-417. http://dx.doi.org/10.1007/s11258-014-0445-5.

Deng, X., Hu, Z.A., Wang, H.X., Wen, X.G., Kuang, T.Y., 2003. A comparison of photosynthetic apparatus of the detached leaves of the resurrection plant Boea hygrometrica with its non-tolerant relative Chirita heterotrichia in response to dehydration and rehydration. Plant Sci. 165, 851-861 doi: 15982 , 35400011291391.0210.

Dußois, M., Gilles, K.A., Hamilton, J.K., Rebers, P.A., Smith, F., 1956. Colorimetric method for determination of sugars and related substances. Anal. Chem. 28, 350-356. http://dx.doi.org/10.1021/ac60111a017.

Flexas, J., Barbour, M.M., Brendel, O., Cabrera, H.M., Carriquí, M., Díaz-Espejo, A. et al., 2012. Mesophyll diffusion conductance to $\mathrm{CO}_{2}$ : an unappreciated central player in photosynthesis. Plant Sci. 193, 70-84.

Garcia, P.M., Hayashi, A.H., Silva, E.A., Figueiredo-Ribeiro, R., de, C., Carvalho, M.A.M., 2015. Structural and metabolic changes in rhizophores of the Cerrado species Chrysolaena obovata (Less.) Dematt. as influenced by drought and re-watering. Front. Plant Sci. 6, 721. http://dx.doi.org/10.3389/fpls.2015.00721.

Grassi, G., Magnani, F., 2005. Stomatal, mesophyll conductance and biochemical limitations to photosynthesis as affected by drought and leaf ontogeny in ash and oak trees. Plant, Cell Environ 28, 834-849. http://dx.doi.org/10.1111/j.13653040.2005.01333.x.

Havir, E.A., McHale, N.A., 1987. Biochemical and developmental characterization of multiple forms of catalase in tobacco leaves. Plant Physiol. 84, 450-455.

Hendry, G.A.F., Price, A.H., 1993. Stress indicators: chlorophylls and carotenoids. In: Hendry, G.A.F., Grime, J.P. (Eds.), Methods in Comparative Plant Ecology. Chapman Hall, London, pp. 148-152.

Hoffmann, W.A., Orthen, B., Franco, A.C., 2004. Constraints to seedling success of savanna and forest trees across the savanna-forest boundary. Oecologia 140 252-260. http://dx.doi.org/10.1007/s00442-004-1595-2.

IPCC, Intergovernmental Panel on Climate Change, 2007. Climate change 2007: synthesis report. In: Pachauri, R.K., Reisinger, A. (Eds.), Contribution of Working Groups I, II and III to the Fourth Assessment Report of the Intergovernmental Panel on Climate Change. IPCC, Geneva, Switzerland.

Lam, H.M., Coschigano, K.T., Oliveira, I.C., Melo-Oliveira, R., Coruzzi, G.M., 1996. The molecular-genetics of nitrogen assimilation into amino acids in higher plants. Annu. Rev. Plant Physiol. Plant Mol. Biol. 47, 569-593. http://dx.doi.org/10.1146/ annurev.arplant.47.1.569.

Lawlor, D.W., Cornic, G., 2002. Photosynthetic carbon assimila-tion and associated metabolism in relation to water deficits in higher plants. Plant, Cell Environ 25, 275-294.

Lorenzi, H., 2002. Árvores Brasileiras: Manual de identificação e cultivo de plantas arbóreas nativas do Brasil. Plantarum, Nova Odessa, São Paulo.

Lunt, I.A., Hubbard, S.S., Rubin, Y., 2005. Soil moisture content estimation using ground-penetrating radar reflection data. J. Hydrol. 307, 254-269. http://dx.doi. org/10.1016/j.jhydrol.2004.10.014.

Machado, R.B. Ramos Neto, M.B., Pereira, P.G.P., Caldas, E.F., Goncalves, D.A., Santos, N.S., Tabor, K., Steininger, M., 2004. Estimativas de perda de área de Cerrado brasileiro. Conservação Internacional, Brasília.

Mekonnen, D.W., Flügge, U.I., Ludewig, F., 2016. Gamma-aminobutyric acid depletion affects stomata closure and drought tolerance of Arabidopsis thaliana. Plant Sci. 245, 25-34. http://dx.doi.org/10.1016/j.plantsci.2016.01.005.

Muller, B., Pantin, F., Génard, M., Turc, O., Freixes, S., Piques, M., Gibon, Y., 2011. Water deficits uncouple growth from photosynthesis, increase $C$ content, and modify the relationships between $C$ and growth in sink organs. J. Exp. Bot. 62 (6), 1715-1729. http://dx.doi.org/10.1093/jxb/erq438.

Myers, N., Mittermeier, R.A., Mittermeier, C.G., Fonseca, G.A.B., Kents, J., 2000 Biodiversity hotspots for conservation priorities. Nature 403. http://dx.doi.org/ 10.1038/35002501, 853-558.

Oliveira, P.S., Marquis, R.J., 2002. The Cerrados of Brazil: Ecology and Natural History of a Neotropical Savanna. Columbia University Press, New York.

Oliver, M.J., Guo, L., Alexander, D.C., Ryals, J.A., Wone, B.W.M., Cushman, J.C., 2011 A sister group contrast using untargeted global metabolic analysis delineates the biochemical regulation underlying desiccation tolerance in Sporobolus stapfianus $[\mathrm{C}][\mathrm{W}][\mathrm{OA}]$. Plant Cell 23, 1231-1248. http://dx.doi.org/10.1105/ tpc. 110.082800 .

Petrov, V., Hille, J., Mueller-Roeber, B., Gechev, T.S., 2015. ROS-mediated abiotic stress-induced programmed cell death in plants. Front. Plant Sci. 69, 1-16. http://dx.doi.org/10.3389/fpls.2015.00069.

Reddy, A.R., Chaitanya, K.V., Jutur, P.P., Sumithra, K., 2004. Differential antioxidative responses to water stress among five mulberry (Morus alba L.) cultivars. Environ. Exp. Bot. 52 (1), 33-42. http://dx.doi.org/10.1016/j.envexpbot.2004.01.002.

Renault, H., El Amrani, A., Palanivelu, R., Updegraff, E.P., Yu, A., Renou, J.P., et al., 2011. GABA accumulation causes cell elongation defects and a decrease in expression of genes encoding secreted and cell wall-related proteins in Arabidopsis thaliana. Plant Cell Physiol. 52, 894-908. http://dx.doi.org/10.1093/pcp/ pcr041.

Robertson, F., Skeffington, A., Gardner, M., Webb, A.A.R., 2009. Interactions between circadian and hormonal signalling in plants. Plant Mol. Biol. 69, 419-427. http:// dx.doi.org/10.1007/s11103-008-9407-4.

Shukla, N., Awasthi, R.P., Rawat, L., Kumar, J., 2012. Biochemical and physiological responses of rice (Oryza sativa L.) as influenced by Trichoderma harzianum under drought stress. Plant Physiol. Biochem. 54, 78-88. http://dx.doi.org/ 10.1016/j.plaphy.2012.02.001. 
Stitt, M., Sulpice, R., Keurentjes, J., 2010. Metabolic networks: how to identify key components in the regulation of metabolism and growth. Plant Physiol. 152, 428-444 doi: org/10.1104/pp.109.150821.

Tanaka, Y., Sugano, S.S., Shimada, T., Hara-Nishimura, I., 2013. Enhancement of leaf photosynthetic capacity through increased stomatal density in Arabidopsis. New Phytol. 198 (7), 57-64. http://dx.doi.org/10.1111/nph.12186.

Toscano, S., Farieri, E., Ferrante, A., Romano, D., 2016. Physiological and biochemical responses in two ornamental shrubs to drought stress. Front. Plant Sci. 12, 645. http://dx.doi.org/10.3389/fpls.2016.00645.

Veiga, E.B., Habermann, G., 2013. Instantaneously measured traits may detect nonplastic ecophysiological performances in response to drought, explaining distributions of Styrax species in the Cerrado. Trees 27, 1737-1745. http:/ dx.doi.org/10.1007/s00468-013-0919-4.
Yang, L., Han, M., Zhou, G., Li, J., 2007. The changes of water-use efficiency and stoma density of Leymus chinensis along Northeast China Transect. Acta Ecol. Sin. 27, $16-24$.

Yang, F., Xu, X., Xiao, X., Li, C., 2009. Responses to drought stress in two poplar species originating from different altitudes. Biol. Plant 53, 511-516. http:// dx.doi.org/10.1007/s10535-009-0092-1.

Zhao, W., Sun, Y., Kjelgren, R., Liu, X., 2015. Response of stomatal density and bound gas exchange in leaves of maize to soil water deficit. Acta Physiol. Plant 37, 1704 http://dx.doi.org/10.1007/s11738-014-1704-8.

Zivcak, M., Brestic, M., Balatova, Z., Drevenakova, P., Olsovska, K., Kalaji, H.M., Yang, X., Allakhverdiev, S.I., 2013. Photosynthetic electron transport and specific photoprotective responses in wheat leaves under drought stress. Photosynth Res. 117, 529-546. 